\title{
The Quest for a Cultural Identity in Derek Walcott's Another Life
}

Amany Abdelkahhar Aldardeer Ahmed

\section{Abstract}

This paper explores the quest for a cultural identity in the colonial and postcolonial Caribbean society that inspire Derek Walcott to write Another Life. Walcott has conducted a lifelong struggle to integrate his divided identity because of the multicultural properties of the Caribbean society. Critical analysis of Walcott's autobiographical work, Another Life, reveals his main concern with the postcolonial Caribbean identity and the complexities of the Caribbean West Indian society. Another Life explores the Caribbean society and its history in colonial and postcolonial contexts. Walcott blends themes associated with his heritage, his West Indian culture, British Rule, and inequality in Another Life. The prevalence of completely different cultures in the colonial period led to a severe identity crisis and fragmentation in the Caribbean postcolonial age. An examination of Walcott's Another Life shows the cultural divisions he experienced in the West Indies and the identity issues that associate with his multicultural origin.

\section{The Purpose of the study}

The primary purpose of this paper is to identify the dominant thematic and technical patterns employed by Walcott in relation to the multiculturalism and the complex process of identification as shown in Another Life. Multiculturalism is a

${ }^{(*)}$ This paper is a part of $\mathrm{PhD}$. thesis entitled: " Multiculturalism and the Quest for a Cultural Identity in the Poetry of Derek Walcott". Supervised by Prof. Fawzia M. Aly Gadalla - Faculty of Arts-Sohag University \& Prof. Ahmed Abdellah Elsheemi- Faulty of Languages Bani-Suef University \& Prof. Catherine A. John- Department of English- Faculty of Arts, Oklahoma University \& Dr. Thana A. Elkady- Faculty of Arts-Sohag University. 
defining feature of Walcott's writings and it came as a result of his postcolonial Caribbean experience and his multivocality which appears in several ways: different dialogues of different cultures, multiple voices and characters in one single poem. These multicultural aspects reveal the challenge within the poet himself and his feeling of ambivalence which inspired him to search for a Caribbean cultural identity.

\section{Review of the Literature:}

Many writers have discussed the dilemma of the Caribbean identity and the great effects of colonialism on shaping the multicultural Caribbean society. Many critics have touched on several issues of the Caribbean multiculturalism and on Walcott's search for the Caribbean cultural identity, but their focus have been broad, treating the major concerns of Walcott's literary works. One of the major articles that discusses Walcott's major themes in Another Life, is Dominique's Delmaire's "Derek Walcott's Another Life: from Death to Celebration". Delmaire points out that "identity breaks up into a multiplicity of selves in any autobiographical project, because of the time gap between who the poet was then and who he is now"(5). It is important to recognize the importance of a postcolonial reading of Walcott's poetry. In her article, "Giotto's Invisible Sheep: Lacanian Mirroring and Modeling in Walcott's 'Another Life", Judith Harris shows Walcott's interest in questing a Caribbean identity. Harris illustrates: "Walcott insists that the West Indian must have a vision of him- or herself that more closely corresponds to what he or she is now rather than to where he or she came from"(306). Another article that deals with the dilemma of the Caribbean identity in Walcott's Another Life is Catherine Douillet's "The Quest for Caribbean Identities: Postcolonial Conflicts and Cross-Cultural Fertilization in Derek Walcott's Poetry". Douillet came to the conclusion that " the Caribbean is characterized by its complex process of creolization between Europeans and Africans"(6). 
Walcott, therefore, succeeded in his poetry to create literature inspiring with his profound sense of fragmented cultural identity and severe feeling of pain and loss. Therefore, This paper demonstrates Walcott's devotion to questing the Caribbean identity as reflected in Another Life.

\section{Methodology}

As this paper concerns with Walcott's quest for a Caribbean cultural identity, the researcher's argument suggests that postcolonial theory should be essential to the readings of Walcott's Another Life. This paper focuses on the major postcolonial concepts and the argument has been grounded on the fact that the conflict between the colonizer and the colonized and what it caused of Caribbean ambivalence and mimicry. The researcher adopts the work of several postcolonial theorists, including Homi Bhabha, Frantz Fanon, Edward Said and Bruce King in analyzing Walcott's poems. The researcher uses methods of postcolonialism in dealing with Walcott's poetry. Adopting the postcolonial strategies, Walcott critically engages himself with the concepts of multiculturalism, home, identity, hybridity and heritage.

\section{Significance of the Study}

This paper tries to probe the ambivalent and the hybrid feelings of the Caribbean people, their fight for recognition and identification as represented in Walcott's Another Life. The researcher attempts to illustrate, in this paper, that Walcott's contribution to the West Indian literature is to create a new Caribbean identity and that his work develops over time to go with the development of the Caribbean identity. The researcher's primary objective in this paper is to investigate instances of multiculturalism and cultural identity in Walcott's Another Life that operate on two axes: culture and identity.

\section{3}


Walcott engages himself in search of identity and in the assimilation of the varied culture and the paradox of his hybrid inheritance. The question of identity is one of the most frequently recurring themes in the poetry of Walcott. The Caribbean character is in conflict of gaining acceptance and acquiring self-identity. As he lived the Caribbean experience, Walcott is shattered between his African heritage and his Caribbean identity. The feelings of humiliation, diaspora and dispossession is close to the Caribbean culture. The researcher revealed that there is always a struggle inside the poet between his classical sense which is a direct result of Colonialism and his commitment to his St.Lucian society.

The feeling of multiracial and multicultural identity is one of Walcott's major concerns in writing Another Life. Consequently, he spent his life not only in searching for a Caribbean identity, but also in creating a new identity devoid of any feeling of double consciousness or ambivalence. This paper uses the methods of postcolonialism in dealing with Walcott's Another Life concentrating on Bhabha's concepts of ambivalence, mimicry and language as they best reflect Walcott's style of writing. Bhabha focuses his theory of cultural hybridity(the same as the Caribbean) primarily on language. In order to understand the cultural identity and the hybridity of the Caribbean, it is important to focus on Bhabha's meaning of hybridity. In his book, The Location of Culture, Bhabha articulates:

Hybridity is the sign of the productivity of colonial power, its shifting forces and fixities; it is the name for the strategic reversal of the process of domination through disavowal (that is, the production of discriminatory identities that secure the 'pure' and original identity of authority). Hybridity is the 
revaluation of the assumption of colonial identity through the repetition of discriminatory identity effects. It displays the necessary deformation and displacement of all sites of discrimination and domination. (160)

In Bhabha's terms, the Caribbean society became a hybrid society as it is caught between the European culture and the culture of the indigenous people. This helped in creating a feeling of merged or loss of identity and erasure of history and language. Most of the Caribbean people lost their original language and instead of fighting for restoring their language, they themselves use the English language unconsciously.

One of the inherent evils of colonialism is that the colonizer regarded the colonized as inferior and underdeveloped. Edward Said's theory of colonial discourse shaped the relationship between the colonizer and the colonized in their "texture of linguistic and cultural practices"(Said, The World, the Text and the Critic 83). His theory is based mainly on the assumption of the colonizer's obvious superiority in all the cultural and the political aspects. Said, commenting on the Caribbean colonized identity, asks: "how does a culture seeking to become independent of imperialism imagine its past"(Said, Culture and Imperialism 120). Focusing on Said's concepts of the colonizer and the colonized, Walcott seeks to identify the colonial and postcolonial Caribbean history and the effect of colonialism on the Caribbean society. "Looking at the immediacies of the colonial context. It is clear that what divides this world is first and foremost what species, what race one belongs to... You are rich because you are white and you are white because you are rich" (Fanon, The Wreched of the Earth 5). Living in the same conditions, 
Walcott is involved in the search for the Caribbean identity and the West Indian heritage and he recognized the importance of the African ancestry of the black West Indians.

Another life "is a transitional work in Walcott's selfarticulation"(Casteel 5). It describes Walcott's life and his continuous search for a Caribbean individuality and identity which is lost in a colonial society. Walcott asserts, through the work, that colonialism has left a distorted history of the Caribbean and created feelings of loss and alienation. The poem, then, uncovers not only Walcott's feelings of inadequacy and fragmentation but also the feeling of indifference of his society towards literature:

How often you have felt you have wasted your life among people with no moral centre, to want to move from the contagion of too many friends, the heart congealing into stone, how many would prefer to this poem to see you drunken in a gutter, And to catch in the corner of their workrooms the uncertified odour of your death? (Collected Poems2645)

The above lines convey the poet's anguish and depressed feelings on wasting his life among the colonizers (people with no moral centre). The poem is intended to be an autobiography of Walcott's life and Career. It reevaluates the Caribbean history, language and life and assesses Walcott's work as a poet. In Another Life, Walcott turns his personal experience into a literary one, providing his Caribbean vision. In his famous essay "The Muse of History", Walcott summarizes the mood of writing Another Life, "I know, from childhood, that I wanted to become a poet and like any colonial child I was 
taught English literature as my natural inheritance.... There is a memory of imagination in literature which has nothing to do with actual experience, which is, in fact, another life"(25). The poem takes the reader to a new beginning- a beginning towards the poet's another life.

Another Life is an extra ordinary work of literature in the Caribbean canon in the sense that it is written in four books and twenty-three sections in which Walcott covers all aspects of the Caribbean postcolonial life through depicting his personal experience. "The texture, color, tone of the poet's childhood on St.Lucia and his rites of initiation into manhood and art are matched by a language so rich and sensuous that one feels in it that rare balance between the personal life and the fully metaphorical meaning of that life"(Balakian 172). The work deals with the social, political and religious life of the Caribbean in the West Indies during the colonial and the postcolonial times. Moreover, the poem is considered a distinguished work as it is written in a language that is a mixture of the English and the Caribbean Creole. Walcott is aware of the importance of the time Another Life was published in 1973, so that he makes good use of the traditional forms and styles of writing and that of the Caribbean narrative to match the postcolonial Caribbean.

"It is well known that Walcott's way of redressing the damages - and dressing the wounds - of History's perverse memory is to get out of it and into the realm of Art, and to talk poetry instead of politics"(Loreto 47). Walcott's major concern in writing Another Life is to use his art as a reflection of the social and the political incidents in his society and to search for an individual Caribbean identity in a postcolonial society full of divisions and displacement: 
The publication of Another Life was the impulse for a more sustained, more deeply researched, analysis of what Walcott was doing as a poet... Another Life is a symphony of styles, influences, imitations, echoes, colours, recurring themes, reharmonizations.... The poem is not just about the colonial and Caribbean, but also about the division between a religious view of humanity and the instinctive natural man". (King 310)

Another Life is a long poem sequence reflecting the formation of the racial identification and the resistance to the colonial domination. It is divided into four chapters: "The Divided Child", "Homage to Gregorias", "A Simple Flame" and "The Estranging Sea". Walcott opens the work with remembrance of his childhood.

The first chapter in Another life is entitled "The Divided Child". The title is indicative as it suggests that the poet is divided and struggles both personally and culturally. He is torn between his life in St.Lucia and among the ordinary Caribbean people versus the other life offered by colonialism. "The Divided Child", the first book of the work, typically represents Walcott's life and career as it follows the development of his skill in creating new culture out of the old and creating a new language out of his origin. Because he was born of a racially mixed ancestry, Walcott always had the feeling of "a divided child". Book one of Another Life starts with an epigraph, taken from Malraux' psychology of Art. It shows how the writer is inspired by the world around him. "What makes the artist is the circumstance that in his youth he was more deeply moved by the sight of art than by that of the things which they portray"( Hamner, Derek Walcott 144). Walcott starts his poem directly towards the main theme of his work; the feelings of fragmentation and dislocation of all the Caribbean people: 
Verandahs, where the pages of the sea are a book left open by an absent master in the middle of another life-

I begin here again,

Begin until this ocean's

A shut book, and like a bulb

The white moon's filaments wane(Collected Poems 145)

"The opening of the poem announces its violent subject"; the severe feeling of being shattered and divided between two forces (Breslin 61). Walcott employs the sea as a vital factor in conveying his feelings of pain and injustice, as it witnessed the long years of colonialism which caused such feelings. The sea is described as a book and the waves which are coming in and going out, are the pages of the book. Walcott begins his autobiographical poem Another Life with his contemplation of the sea from which he can begin his life. "The opening lines of Another Life not only evoke the sea as the medium, they actually call it the book itself" (Hambuch 197). For Walcott, the sea is the embodiment of culture, history and identity.

In Another Life, Walcott presents his colonial experience which has alienated him and increased his feeling of estrangement and self-division. Therefore, He develops the theme of the sea in Another Life as a way of reading the Caribbean colonial history and reflecting its effect on Walcott as an islander. "The sea is an inescapable presence in his work and has fundamentally affected his sense of being an islander"(Hirsch 109). In the Caribbean colonial and slavery period, the sea was the means of transport for the slaves to the New World. "The sea, in this context, compares to the writing that remains preserved across time"" (Hambuch 197). As he deals with the theme of death in many of his early poems, Walcott clearly shows the idea of death in his use of "an absent 
master" which reflects the great effect of masters in his life, mainly his father who died when he was only one year old. In his article, "Derek Walcott's Another Life: from Death to Celebration" Dominique Delmaire demonstrates the effect of death on Walcott:

Death, which seems indeed to pervade every area of his life and island at all times, is emblematized in the figure of the 'absent master,' who could equally stand for Harry Simmons, the poet's father, or God, all three dead or about to be.... Yet, the more death contaminates life, the more the poet will attempt to keep it at bay (3).

Perhaps, the most significant influences in Walcott's life was his Methodist religious upbringing and the death of his father at a very early age. Also, there are some people who had great impacts on his life and career. Harry Simmons, a painter and a folklorist, cultivated in Walcott the love for the Caribbean indigenous and urged him to celebrate the beauty of St.Lucia and the Caribbean culture and history.

Another Life defines the characteristics of the Caribbean society which is delimited by nation, class, race and religion. Walcott tries through this work to respond to the St.Lucian community which is determined by the colonial rule. He makes good use of the fragmented culture and transforms the Caribbean into a valid autobiographical work. "Throughout the poem, Walcott alternates between details of his own maturation as an artist and sketches of the townspeople"(Casteel 9). With writing Another Life, Walcott brings the Caribbean identity into existence. "A major impulse is to see the story of his life as reflecting the history of the West Indies, so the poem's more public themes include the clash of cultures in the making of the region, the search for a 
liberating idea of history, and the fatal neglect of the artist by a philistine society" (Baugh, "Derek Walcott" 467). This search for origin and ancestry could be seen clearly in Another Life; the poet has to choose between two forms of artistic expressions:

I looked for some ancestral, tribal country, I heard its clear tongue over the clean stones

of the river, I looked from the bus window and multiplied the bush with savages, speckled the leaves with jaguar and deer (Walcott, Collected Poems 184)

These lines demonstrate that the poet is searching for his origin which is represented in his "ancestral, tribal country" and "its clear tongue" which implies the Caribbean language. Moreover, Walcott makes good use of the figurative language and images that serve his meanings as when he says: "I heard its clean tongue over the clean stones" which carries different images of St. Lucia. Therefore the poet tries to overcome the feelings of rootlessness and focus on the positive building and reconstruction of the Caribbean identity. A study of Walcott's Another Life shows his attempt to produce Caribbean poetry independent of the British tradition, while the style and the language indicate their dependence on English language. "The unusual qualities of Walcott's autobiographical long poem may partly derive from his interest in prose models" (Breslin 156).

Because it is an autobiographical poem, Another Life is a widespread piece of literature as it deals with the poet's own experience as an incarnation of the common Caribbean experience. It also reflects the poet's personal voice through using the first person pronoun in almost all the parts within the 
work. Moreover, it is considered one of the most representative poems in the history of Caribbean literature. Thus, Another Life helps in the development of Walcott's literary career. Richard Dwyer defines it as "a spiritual autobiography narrating the growth of the poet's mind"( Dwyer 5). The poem also represents a social and political record of the Caribbean postcolonial life. Walcott's focus in this poem is on the West Indian culture and identity:

In Another Life, Walcott carefully nurtures and protects this identity he is bringing into existence. He goes back in time to an African past of lyrical beauty and vitality, and this past speaks to him clearly.... The poet's sense of rootlessness does not lead him to a state of total alienation and despair. He channels these feelings into the positive effort of reconstruction in which he is engaged (Bobb 85).

Another Life deals with the poet's growing up and his development as a poet. "Since it deals partly with his growing up, many of the old concerns reappear, but, as would be expected, they also have grown"(Figueroa 148).

The poem establishes the poet's internal feeling of alienation and estrangement even within the poet's own home. As a result of postcolonialism, Walcott has internalized these ambivalent feelings. The tone of anger and despair overwhelms the poem:

Do not tell me the world is the same,

that life is hard as a stone,

for I have known it when it was a flower

potent, annihilating with promise.

that the worest of us are wolves.

I no longer care for whom I write, 
as you found in your hand, sir, that terrabile paralysis of their vindication that out of such a man, nothing would come, they said that, and were already composing, some by a sentence, some by a phrase, some by their spit, (Walcott, Collected Poems 265)

As he lived in a colonial and postcolonial society, Walcott lives the hardships and tensions of his society. In Another Life, Walcott demonstrates his feelings towards the life which he describes as "hard as a stone" and that "nothing would come". In a collective article with Walcott, Edward Hirsch sums up the main reasons of Walcott's tension and anger:

Some of the dramatic tension in his work comes from the gap he has always had to cross to describe the people with whom he shares an island. So, too a great deal of rage sometimes breaks loose in his work as a fury against racism: against those who have typed the poet as neither black nor white enough; against those who still view the Caribbean people as illegitimate and rootless; against the legacies of slavery and colonialism. (Hirsch 108)

In Another Life, Walcott grows increasingly aware of the need to create Caribbean cultural aesthetic that enhances the Caribbean identity, but as it is a postcolonial poem, the full dedication to the Caribbean identity has not yet achieved. However, in writing Another life, Walcott steps forward towards his mature style of writing which is fully dedicated to the Caribbean. "Another life is a preliminary exploration of traditionally marginalized characters, settings, and themes that Walcott considers too valuable to be discounted in the annals 
of New World Literature" (Hamner, Epic of the Dispossessed 22). The poem, then, gathers between the ambivalence of the poet's first stage and the revolution and struggle to stress the national identity in the third stage. The poet portrays different and real character to convey his universal themes of life and death:

Through a frontispiece of flowers

eternal, true as Ruth

the wheat sheaves at her ear,

or gorgonizing Judith

swinging the dead lantern

of Holofemes, that bright year

like all first love, we were

pure and Pre-Raphaelite,

\section{As Gregorias}

bent to his handful of earth,

his black nudes gleaming sweat,

in the tiger shade of the fronds.(Walcott, Collected Poems 202-3)

Character portrayal plays a significant role in conveying Walcott's multiple themes and ideas to achieve his job not just as a poet who is reflecting his society, but also as a reformer who seeks the perfection of his society. Walcott makes good use of the characters Ruth and Judith in the poem. The two characters are contradictory and they are different in their Caribbean attitude. Whereas Ruth is very loyal to her mother in low and in her honesty she is true as in the simile: "through a frontispiece of flowers/ eternal, true as Ruth", Judith assassinates a foreign conqueror and she is portrayed "swinging the dead lantern of Holoferness".Through employing the dramatic monologue in the previous lines, Walcott reveals the strength of the character of Gregorias (a 
Caribbean artist) in creating great images of the Caribbean through his art.

Walcott's job in Another life is to share his Caribbean experience with all his fellow Caribbean people and to assert his continuous quest for Caribbean self-assertion through portraying different Caribbean characters. His main interest is to reveal the fact that colonialism has affected the Caribbean culture in different ways. According to John Thieme: "

Another Life is unequivocally a Caribbean poem, but the intertexts that contribute to its making are primarily European in origin. ... where the poet himself is concerned, love appears to be an intertextual creation long before he turns to rendering it in his writing. His love for 'Anna' clearly owes something to literary texts....and earlier in the poem he has approached her through the mediation of the Book of Hours and the Biblical figures of Ruth and Judith. So, even when the subject of tradition to the fore, Another Life still suggests that fictions of self are original, but derivative reworking of received fictions(93).

Another Life shows Walcott's adoption of the postcolonial strategies in producing characters independent of the colonial influence. Walcott tries also to reveal more about the cultural conflict between Africa and Europe and differences in origin. "In the imagined conflict between an African past and a European future there is no space in which to imagine either a West Indian past or, for that matter, a West Indian future" (Hodges 112). Therefore, the poem dramatizes the poet's experience in the colonial society and examines the way colonization has left a distorted Caribbean history

\section{5}


In Another Life, Walcott returns with his memories of division of St.Lucia to search for his roots and Caribbean origins. He characterized his early stage of life as a "divided childhood. "The Divided Child" is an incarnation of the Caribbean suffering in a colonial society. Moreover, The Caribbean people felt shattered and ambivalent after independence as they lived in a society that denied them their history and supported the colonial side. "In an interview with Edward Hirsch, Walcott sums up the major aspects of his autobiographical work, Another life and says:

What I described in Another Life - about being on the hill and feeling the sort of dissolution that happened-is a frequent experience in a younger writer. I felt this sweetness of melancholy, of a sense of mortality, or rather of immortality, a sense of gratitude both for what you feel is a gift and for the beauty of the earth, the beauty of life around us. When that's forceful in a young writer, it can make you cry. It's just clear tears; it's not grimacing or being contorted, it's just a flow that happens. The body feels it is melting into what it has seen. This continues in the poet. It may be repressed in some way, but I think we continue in all our lives to have that sense of melting, of the "I" not being important. (280)

Therefore, Another Life represents a complete literary work which describes and reevaluates Walcott's life and history and at the same time reflects the early steps of celebrating the Caribbean language. Walcott goes on to draw the whole picture of the Caribbean suffering of colonization which has left a distorted history and says: 
And from a new book,

Bound in sea-green linen, whose lines

Matched the exhilaration which their reader,

Rowing the air around him now, conveyed,

Another life it seemed would start again

While past the droning, tonsured head

The white face

Of a dead child stared from its window -frame.

(Collected Poems149)

These lines show Walcott's examination of the Caribbean's fragmented identity which is the same as his own identity. The poem, therefore, deals with the historical and cultural loss that Walcott himself has experienced. It reveals the poet's argument that is to reevaluate the past and to reconnect with the Caribbean people. The poet has a dream of rebuilding his country and this dream starts to become true when he says: "another life it seemed would start again". Walcott is not only seeking a personal identity but also a regional and communal one. He is never specific about his personal life but he is looking for a new start for all the Caribbean.

As the poem progresses, Walcott hints at the Caribbean lack of identity due to the Caribbean multicultural history. Moreover, it is evident throughout the whole poem that the Caribbean is portrayed as an isolated, divided and that there is always a dream for change and rebirth: the search for another life which is evident in Walcott's use of language and word choice:

There

Was your heaven! The clear

glaze of another life,

a landscape locked in amber, the rare

gleam. The dream 
of reason had produced its monster:

a prodigy of the wrong age and colour.( Collected Poems 145)

Addressing all the Caribbean people, the poet uses the possessive pronoun "your" in addressing his fellow Caribbean, stressing that St. Lucia is their land and the Caribbean is their identity. Questing the Caribbean cultural identity is Walcott's main concern and it is clear in choosing suggestive words such as "heaven", "landscape", "dream". These words enhance the Caribbean search for identity, and give hope for a better future. It is evident in the previous lines that the artist is looking for "another life". He is searching for his identity and this is evident in the line, "a prodigy of the wrong age and colour" for though the poet is talented and has a great art. Walcott, then, is divided between two worlds and he is looking forward to creating a new world for himself.

There are some people who have great effects in Walcott's life. These characters are well presented in Another Life as they have vital roles in shaping his life. In his book: Abandoning Dead Metaphors: The Caribbean Phase of Derek Walcott's Poetry, Patricia Ismond illustrates the major effective figures in Walcott's autobiographical work, Another Life:

Walcott structures the work around the three figures who dominate this combined biography: that of St Omer, called Gragorias in the poem (book 2); that of Anna, the name he gives to Andreuille Alcee, the first love whose story stands for his own (book 3); and that of Simmons, the 'master' of Gregorias and himself (book 4). Around these lives he orchestrates a number of interrelated these, some already familiar from other works of the period. (142) 
The three main names who are repeated in Another Life, Harold Simmons who is Walcott's painting mentor and who is referred to as Harry, Dustin St. Omer who is renamed to Gregorias and Anna, his teenage romance. Each character embodies an artistic vision in the poem. "Walcott describes his artistic development with his friend Dustan St Omer, who is renamed Gregorias in the text. As they stay in Gregorias's house, the artist affectionately chides his friend"(Jefferson):

"Man I ent care if they misunderstand me,

I drink my rum, I praise my God, I mind my business!

The thing is you love death and I love life".

"Your poetry too full of spiders,

Bones, worms, ants, things eating up each other,

I can't read it. Look!"

He frames a seascape in a chair,

\section{"Listen!"}

As if the thunderous Atlantic

Were a record he had just put on.

( Walcott, Collected Poems 206-7)

These lines suggest that Walcott is still learning the lesson of colonialism and has to restore the Caribbean history, culture and language. "Gregorias's two instructions, 'look' and 'listen' suggest that Walcott had to be taught to understand and interpret the everyday scenes of his youth"(Jefferson 296). Unlike his fellow-painter, Gregorias, Walcott ultimately fails to possess the landscape.

Celebrating his love of home is a preoccupation in most of Walcott's poems, especially in his autobiographical work Another Life in which he dedicates many parts to reflect his affection to St.Lucia. The following lines show how Walcott 
and his friend Gregorias (the artist, Dunstan St.Omer) celebrate their love for the island:

That we would never leave the island until we had put down, in paint, in words as palmists learn the network of a hand, all of its sunken, leaf-chocked ravines, every neglected, self-pitying inlet muttering in brackish dialect...( Collected Poems 194)

St. Lucia doesn't only represent a place and a setting for Walcott, but it is a symbol and an incarnation of the Caribbean identity and origin. The repetition of the pronoun "we" in, "we would never leave the island" and "until we had put down" indicate the commonality of the Caribbean experience and that St. Lucia is the land of all the Caribbean people of which there are "leaf-chocked ravines", "every neglected" and "selfpitying". As it is his homeland and the setting of almost all his poems, Walcott gives importance to every aspect in St.Lucia. "This exuberant love for the island and the need to sanctify it in song-along with the significant experiences of his youthcomes across clearly in his earliest poetry"(McWatt 1609).

In book III of Another Life, Walcott presents his story with his lover Anna, one of the main effective figures in his life. Through word choice and the use contradictions and metaphors, Walcott gives a detailed description of his relationship to Anna; his youthful companion. She manifests a purity of spirit and body:

I, said the Negro whore on the drawing-room floor under the silent portraits of your parents, while Anna slept, her golden body like a lamp blown out that holds, just blown, the image of the flame.( Collected Poems 228) 
The poem follows Walcott's life spanning from his feeling of love, ambivalence and contradiction in the Caribbean society. Anna or Andreuille Alcee represents Walcott's first love and who share his feeling of ambivalence. "The Anna experience, representative of Walcott's own story as artist/lover, carries the narrative of love-whose original light/flame is reflected in the idealism, with all the attendant contradictions and ambiguities, embodied in the image of Andreuille Alcee as first love"(Ismond, Abandoning Dead Metaphors 143). Walcott uses real and imaginary characters to convey his themes. He uses Gregorias to convey his theme of art and Anna conveys his love. "Walcott instructs us in Another Life that Anna, Harry and Gregorias are both real and imaginary: that is to say, that they are and mean at the same time and symbolize the same three themes of love, death and art"(Fumagalli, The Flight 71):

The setting and the character depicted in Another Life are very much interconnected. The impact of colonialism and slavery plays a great role in urging Walcott as a poet to search for the Caribbean identity. Another Life narrates the story of Walcott's life from the early years of apprenticeship in a colonial society, through rebellion and protest to a decision to create a new Caribbean identity. The feeling of ambivalence is evident in Another Life in the use of contradictory words and expressions as in the second stanza of the first chapter:

Begin with twilight, when a glare which held a cry of bugles lowered the coconut lances of the inlet, as a sun, tired of empire. Declined. it mesmerized like fire without wind, and its amber climbed the beer-stein ovals of the British fort above the promontory, the sky 
grew drunk with light.( Collected Poems 145)

Starting the line with "Begin with twilight" suggests the ambivalence and uncertainty of the actions of the speaker. As the poem deals with slavery, history and postcolonial issues, The repetition of the word "begin" suggests a new beginning and hints at a sense of renewal in the Caribbean society. The boy portrayed in the poem resembles not only the character of Walcott, but also all the Caribbean people who are dreaming of another life free from all aspects of displacement and marginalization. There are many sections in the poem that present Walcott's dynamic quest into the Caribbean future that is very much affected by the colonial past and the search for an identity in a postcolonial future. The above stanza opens with "twilight" and ends with "light" and describes in between lines the steps of changing and the ambivalence of the implied feelings of being shattered between different identities and races. The lines reflect Walcott's increase awareness of division and the strong feeling of ambivalence which is clearly shown through the use of paradoxes in "twilight" and "light". Then Walcott continues to show what he has found out; that whiteness associates with superiority and strength and other people are "poor negatives":

Well, everything whitens,

All that town's characters, its cast of thousands

Arrested in one still!

As if a sudden flashbulb showed their deaths.

The trees, the road he walks home, a white film,

Tonight in the park the children leap into statues,

Their outcries round as moonlight, their flesh like flaking stone,

Poor negatives! (Collected Poems 151) 
These lines present one of the major narratives in the poem which is Walcott's contemplations of the black children in St. Lucia and how their blackness is very much related to inferiority. The use of words help understanding the black/white paradoxes. Employing negative words such as, "deaths", "outcries", "flacking stone" and "poor negatives" portray a painful image of the Caribbean black children. Moreover, the previous lines indicate the strong connection between the Caribbean landscape and the identity especially in the two lines, "The trees, the road he walks home, a white film/ tonight in the park the children leap into statues". This indicates that everything in St.Lucia remind its people of colonialism; even the trees and the road.

Through depicting the pictures of his own life and narrating the real incidents of the West Indian society, Walcott asks his people not just to have pride in their Caribbean identity but also to have pride in their own language. In "What the Twilight Says", Walcott emphasizes the importance of keeping the Caribbean language in his poems and stresses that, what saves the Caribbean people from colonialism is "the forging of a language that went beyond mimicry, a dialect which had the force of revelation as it invented names for things, one which finally settled on its own mode of inflection, and which began to create an oral culture of chants, jokes, folksongs and fables"(Walcott, What the Twilight 17). Employing metonymy of black people who are "poor negatives" displays the negative impact of colonialism which extends throughout the whole poem as the following lines depict:

Skin wrinkles like paint, the forearm of a balustrade freckles, crow's feet radiate from the shut eyes of windows, and the door, mouth clamped, reveals nothing, 
for there is no secret

but a pain so a live that

to touch every ledge of that house edges a scream

from the burning wires, the nerves

with their constellation of cancer.( Collected Poems 156)

Walcott employs many images to convey the picture he draws of the Caribbean society. In this society "skin wrinkles like paint" and "the forearm of balustrade freckles". Therefore, the impact of colonialism affected every aspect of the society in which there is no secret "but a pain so a live that/ to touch every ledge of that house edges a scream".

As Another Life traces the poet's personal experience in St.Lucia, Walcott illustrates, in many parts of the poem, the role played by his mother in forming his social and literary life. He skillfully presents a detailed description of his mother and says:

Finger each object, lift it

from its place, and it screams again

to be put down

in its ring of dust, like the marriage finger

frantic without its ring;

I can no more move you from your true alignment,

Mother, than we can move objects in paintings.

(Collected Poems 157)

As a teacher, his mother instilled in him his fondness of poetry and drama, especially English literature and classics. In this way, Walcott had a strong tie with her, and he owes her favor and which is evident in the final two lines of the poem: "Your house sang softly of balance,/ of the rightness of placed things(Collected Poems 157). These two lines add 
to the strong relationship between Walcott and his mother, to whom he owed "the rightness of placed things".

Walcott depicts the communal life of St. Lucia more comprehensively in Another Life as it is an autobiography of his life in St. Lucia. The parts in this work are representative instances of his concern with community and belongings. Rewriting history and reconnecting the several parts of the Caribbean psyche becomes the task of Walcott in his second stage of writing. "The craft of the poem is also appreciable in the way in which the poet shapes the episodic narrative" (Baugh, Derek Walcott 93). Employing aspects of the Caribbean language is also an evident feature of questing a national identity. "Nation-language is often musical, incantatory, panegyric, and poetic" (Alabi 341). The following lines reflect the poetic use of language in employing contradiction, music and repetition:

three lives dissolve in the imagination,

three loves, art, love, and death,

fade from a mirror clouding

with this breath, not one

is real, they cannot live or die,

they all exist, they never have

existed: Harry, Dunstan,

Andreuille. (Walcott,

Collected Poems 257)

The repetition of "three", the alliteration of "lives" and "loves" and the contradiction between "live" and "die", portray an image of uncertainty and perplexity the Caribbean lived through in St.Lucia. 
The sea for the Caribbean people is very important as it is sometimes a way of learning the history of the ancestors. "The Caribbean Sea unifies and names Walcott's political and cultural geography, as well as the common experience of this people. He forges a mythic cycle that explains this new culture and social structure and its embeddedness in the geography of the Caribbean."(CahillBooth 349). In Chapter 22 of Another Life, Walcott portrays an image of the Caribbean children who have lost their cultural identities and the history of their forefathers and that they regard the sea as a source of hope of restoring their origin. "The children have a vague sense of their past as a fusion of diverse races and origins(Margaret Walcott is part East Indian, part Afro-Caribbean, while Derek Walcott, as his poetry often reminds us, has African, English, and Dutch ancestry) "(Breslin 185). Walcott describes the dilemma of the Caribbean children and writes:

That child who sets his half-shell afloat in the brown creek that is Rampanalgas Rivermy son first, then two daughterstoward the roar of waters, towards the Atlantic with a dead almond leaf for a sail, with a twig for a mast, was, like his father, this chils,

a child without history, without knowledge of its preworld,

only the knowledge of water runnelling rocks (Collected Poems 285).

Walcott succeeds in summarizing the idea of identity crisis in two lines: "like his father, this child/ a child without history". The poem touches that cynical aspect of the Caribbean people - the loss of identity and the erasure of their history. "Born into this unjustly diminished Caribbean 
world, of racially mixed ancestry, and far removed from the European world of which he read as he matured, how could he become anything but 'a divided child?'"(Nicholas 136). As his main aim in writing Another Life is to search for the Caribbean identity, Walcott completes the image of his child who tries to search for his history in the sea:

that child who puts the shell's howl to his ear, hears nothing, hears everything that the historian cannot hear, the howls of all the races that crossed the water, the howls of grandfathers drowned (Collected Poems 285).

Through Another Life, Walcott becomes the voice for all the Caribbean people. Therefore, he employs a first person point of view which mirrors the Caribbean status of division and ambivalence. "The point of view is the boy's, which lends a sense of immediacy, but this perspective is also enriched by the more pervasive reflections of the older narrator's longer view"(Harris 301).

As the colonial culture transformed the Caribbean history into fragments and scattered heritage, the sea then is a symbol of healing in the Caribbean culture and history. "This heritage is too tangled and extensive to be made articulate, unless through poetry; the shell is an "intricately swivelled Babel"'(Breslin 285). This tragic experience is personal and autobiographical. Walcott succeeds in converting his personal experience into a communal Caribbean one. In other words, he used the personal pronoun in stating the problem and says: "my son", afterwards he changed into a general case and says: "a child without history" and "that child" in order to assure that it is the case of all the Caribbean children to lose their history. 
As he devoted his works in the second stage of his literary development to questing the Caribbean identity, Walcott highlights the problematic nature of the fragmentary Caribbean identity. He tries to employ the Caribbean history and inheritance in Another Life as in the following passage:

$\mathrm{O}$ sun, on that morning, did I not mutter towards your holy, repetitive resurrection, "Hare, hare Krishna," and then, politely, "Thank you, life"?

( Collected Poems 288)

In his use of personification in addressing the sun in "O sun", the poet shows the importance of the sun in his life as a source of hope. In her book, Historical Thought and Literary Representation in West Indian Literature, Nana Wilson-Tagoe illustrates the role of the sun as the source of hope and creativity:

This sun, symbol of the truth, source of the poet's creativity and element of his imagination, now becomes an all-embracing symbol of history, not of linear history or of a tiered and ordered history in a conventional sense but the human history of endurance and survival which is the poet's inheritance. (155)

Employing the symbol of the sun at the end of his poem, Walcott intends to demonstrate the Caribbean renewal of their life and history. He gives hope to end the long years of ambivalence and displacement and to have a new beginning in life. 
On the personal and the national levels, Walcott continually emphasizes the search for identity. As Another Life stresses the themes of the struggle of the enslaved and oppressed people to quest their lost identity, Walcott critically engages himself with the concepts of home, identity and heritage of the Caribbean. He also writes:

I was seized by a pity more profound than my young body could bear, I climbed with the laboring smoke, I drowned in laboring breakers of bright cloud, Then uncontrollably I began to weep,

Inwardly, without tears, with a serene extinction

Off all sense; I felt compelled to kneel,

I wept for nothing and for everything,

I wept for the earth of the hill

under my knees, For the grass, the pebbles, for the cooking smoke

Above the labourers' houses like a cry. (Collected Poems 18485).

The over-repetition of the first person pronoun "I" indicates the real Caribbean experience of the poet and his continuous search for his roots and origins. "But his willingness to search for his roots in the roots of his own soil eventually leads Walcott to the epiphany that appears to have shaped his poetic mission"(Handley 303). Moreover the repetition of the verb "weep" stresses the poet's feelings of pain and sorrow over the grim conditions of the Caribbean who suffered from colonial persecution and postcolonial fragmentation. The theme of the previous lines is evident in the two lines; "I wept for nothing and for everything,/ I wept for the earth of the hill under my knees". Therefore, the poet draws a sad image of the Caribbean who was subject to colonial prejudice and persecution.

\section{9}


In many of his early and late poems, Walcott always sees culture through the Caribbean sea. Several sections in Walcott's Another Life in his second stage of questing a Caribbean cultural identity deal with the theme of the sea as an embodiment of history and that it has a cultural significance for the Caribbean people. Walcott, drawing from his personal experience, portrays the sea as the witness of all the Caribbean social and political incidents. Therefore, he uses the image of the sea to symbolize the changing conditions of the Caribbean. "Locating a personal identity in the sea gives him a theme and form to materialize his poetic vision and voice and he dedicates his practice to exploring the images he saw written into this place - all of which were visions that had never been interpreted in his received knowledge of poetry"(CahillBooth 349):

I saw history through the sea-washed eyes of our choleric, ginger-haired headmaster, beak like an inflrned hawk's, a lonely Englishman who loved parades, sailing, and Conards's prose.

When the war came the mouths began to bleed, The white wounds put out tongues.( Collected Poems 212)

Walcott dedicated much room to the notion of the sea in different aspects. "He realizes the sea as the gateway between the Caribbean's ancestral traditions and new beginnings and realizes himself as water, an agent of crossing. The sea is not memorialized as a rupture with ancestry, but as the origins of a new civilization"(Cahill-Booth 349). The poet explores his literary heritage and history through using a unique style that is a mixture of his love of standard English and cultivation of a national consciousness. The search for roots and identity has 
resulted in an intimate relationship between the island and the people.

In Chapter nine of Another Life, Walcott contrasts his own style of writing with that of his friend Gregorias through presenting the internal conflict between the classical and romantic techniques of writing. Significantly, Gregorias is depicted as a romantic artist who prefers spontaneity and feeling to the classical model of apprenticeship that Walcott follows:

while

Gregorias abandoned apprenticeship

to the errors of his own soul, it was classic versus romantic perhaps, it was water and fire,

I admired the explosion of impulse,

I envied and understood

his mountainous derision

at this sidewise crawling, this classic

condition of servitude.

His work was grotesque, but whole(Collected Poems 201).

Walcott endeavors to search for the Caribbean dignified sense of the past. The poet uses the past tense to match his speech about his early stage of "apprenticeship". His use of contradiction asserts his ambivalence; "it was classic versus romantic" and "it was water and fire". The poem is central in the exploration of the Caribbean identity and its stages of development. Within the context of exploring the Caribbean identity, Walcott examines the Caribbean settings and the representations of the Caribbean people in Another Life. Most 
of the images employed in this work can be interpreted to serve the quest for the Caribbean identity:

And so one summer after I

return, we arranged to stay in the

old village and we spent two

days and one night there, but

except

for the first few hours it was

somehow different, as if either the

island or myself had changed, but

not Gregorias, and we both spent

a bad night sleeping on our

shoes for pillows,

\section{(Collected Poems 255)}

On leaving the island, the poet takes a look at things that would not say what they once meant. "Upon his return home Walcott's narrator finds nothing is the same as it was"(Dance 5). Walcott uses the past tenses to indicate the change and the difference in the course of the Caribbean life. The description is suggestive and it conveys the theme of reevaluating the Caribbean history in a new life, which "was somehow different". The poet is uncertain and the feeling of confusion overwhelmed him; he declares: "as if the island or myself had changed".

The language employed in Walcott's Another Life demonstrates his theory of multiculturalism in the way he uses European forms and mythology as well as employing the Caribbean indigenous folklore as a way of recovering the Caribbean identity. In doing so, Walcott is recording a stage of development in the West Indian Caribbean culture. He is aware of the loss and the erasure of the Caribbean history and 
the denial of the Caribbean identity on the hands of the colonizers:

But we were orphans of the nineteenth century,

sedulous to the morals of a style,

we lived by another light,

Victoria's orphans, bats in the banyan boughs.

Dragonfly, dragonfly

over that gilded river

like teatime afternoons with the Old Masters,

in those long pastoral twilights after the war.( Collected

Poems 219)

In these lines, Walcott repeats the word "orphans" in "we were orphans of the nineteenth century" and "Victoria's orphans" to stress the idea that he needs to end his dependence on English tradition and to quest a new Caribbean culture. The poem reflects Walcott's success in depicting the fragmented Caribbean culture in a way helps in searching a new Caribbean identity. The poem, then, is a record of Walcott's struggle to find personal and racial identity. The style and the themes of Another Life supports Walcott's quest, using both Creole and English language in the poem. This resulted in confrontation of the Caribbean with the difficulties to live in a multicultural and multiracial society.

One of the main reasons of Walcott's writing Another Life is to reveal the pain and the suffering of the Caribbean and to search for the denied Caribbean history and identity. In this autobiographical poem, "Walcott recalls of the inconsolable burden of innocence and experience of a people breaking out of the aching silence of colonial defects, cracking the solitude of underdevelopment and neo-colonialism, is the most truly remarkable personal cri de Coeur (a cry from the heart) so far 
published by any Caribbean writer I know" (Salkey, "Inconsolable Songs" 51). The work reflects Walcott's concern with the West Indian society in particular and the Caribbean community in general. As the West Indies was colonized for a long time, it lost not only the history and the identity of its people, but also the indigenous characteristics of its people through introducing different cultures to their culture. This created a sense of fragmentation and displacement in the Caribbean West Indian society and also increases the feeling of ambivalence for the poet himself who repeats: "I looked for some ancestral, tribal country"(Collected Poems 184). The poet is always in a case of searching for his origin.

As it is an autobiographical work, Another Life is full of many incidents which all help understanding the Caribbean nature and searching for the Caribbean identity. In book four of the work which is entitled "The Estranging Sea", Walcott gives examples of his continuous quest for the Caribbean identity and that his race is "a stigma" because it is a colonized race that implies inferiority and weakness:

but I need to write them, or I myself would not believe that the world has left such men, that the race is still a stigma, that the truth is nothing more than a puddle of clear water dammed in a ditch. Still, master, I cannot enter the inertia of silence.( Collected Poems 266)

However, Walcott closes book one of Another Life with significant lines that reflect his celebration of the Caribbean language and his love of art when he says: "that he fell in love with art,/ and life began"(186). In his article "The Exile and the Prodigal: Derek Walcott as West Indian Poet", D.S Izevbaye 
explores Walcott's achievement and his great skill in art and the use of language:

Walcott's skill in creating new meaning out of old, that is, the creations of a new language based on his commitment to Standard English and his mythohistoric interpretation of West Indian identity, is a central part of Walcott's achievement. The achievement is made possible by Walcott's commitment to the integrity of his art. It does entail sacrifices; art is life. (89)

In Another Life, Walcott uses the poem not just to reflect his personal life, but it is rather a reflection of the St.Lucian Caribbean life. "This cultural function of the poet does imply not just a special talent but a special way of viewing reality. Art is the element in which he has his being, and to be meaningful, reality must be seen through its lens. The measure of reality in Walcott's poems is thus often literary"(Izevbaye 80). Therefore, the poet is very careful in choosing words that convey his meanings. In the following lines, Walcott declares that he is the first Caribbean poet who deals with the West Indian history and problems in his poems:

For no one had yet written of this landscape

that it was possible, though there were sounds

given to its varieties of wood;

whole generations died, unchristened, growths hidden in green darkness, forests

of history thickening with amnesia, so that a man's branched, naked trunk, its roots crusted with dirt, swayed where it stopped, remembering another name.

(Collected Poems 195-6) 
Walcott is aware that "West Indians were the most modernized because of their long relationship with Western traditions and the loss of classic traditional ancestral ways of seeing" (Lai 180). Therefore, he tries to reflect his anger and refusal towards the erasure of the West Indian Caribbean culture which he shows as "its roots crusted with dirt" and "whole generations died". Consequently, Walcott is looking in his past for "another name" that gives him another identity.

One of the representative parts of Another Life in book two is the poet's Homage to Gregorias which "foregrounds Walcott's ambivalent colonial situation"(Thieme 91). Walcott, the divided child, feels displaced and shattered between two forces; the colonial power which is superior and the national colonized culture which is represented as inferior:

I had entered the house of literature as a houseboy, filched as the slum child stole, as the young slave appropriated those heirlooms temptingly left with the Victorian homilies of Noli tangere (Collected Poems 219).

Walcott describes his intrusion to the field of literature, using new expressions as: "a houseboy", "the slum child", and "the young slave". These lines stress the themes of the struggle of the enslaved and oppressed people of the colonial and postcolonial Caribbean. As he was born in a colonial society where the British rule was a constant factor in his life and that colonialism is a major part of his Caribbean experience, Walcott became heavily influenced by all the aspects of colonialism. As a result, he describes himself as "a houseboy" who steals something that is not 
his; that he got colonial education and language. The poem reveals Walcott's struggle to locate himself as a writer among a multitude of different readers. The lines show that Walcott "is not assimilated, but rather assimilates for his own ends"(Thieme 91). Therefore, the poem shows Walcott's devotion to his people despite his feeling of ambivalence. The theme and the setting of the poem are derived from the Caribbean society. The use of the possessive pronouns in "my body", "my wine" and "our fathers" demonstrates the poet's sense of belonging to the Caribbean culture and illustrates his aspiration to restore the Caribbean heritage and freedom.

In Chapter nine of Another Life, Walcott probes in the "relationship between self and landscape as one that is outside of time and that, like the close reading of verse, argues for the contentious, isochronal mode of recognition suitable for change. Nation, in Walcott's poetics, is not only embedded within imagination but is also subject to the I/eye, as well as to what I/eye had"(Phillips 126). As a painter, Walcott draws a beautiful and natural image of the landscape and says:

There are already, invisible on canvas, lines locking into outlines. The visible dissolves

in a benign acid. The leaf insists on its oval echo, that wall breaks into sweat, oil settles in the twin pans of the eyes

Blue, on the tip of the tongue, and this cloud can go no further.

Over your shoulder the landscape Frowns at its image(Collected Poems 197) 
The use of images supports the meaning of the poem especially the use of metaphors that stresses the beauty of the landscape as in "benign acid", "oval echo", "the twin pans" and "over your shoulder the landscape". The "landscape" is significantly used in the poem as it resembles the St. Lucian landscape which is over the shoulder of the Caribbean who is responsible for representing it in a beautiful image.

Another Life carries the narratives of Walcott's growing up in St.Lucia from his early apprenticeship years through colonialism and Walcott's decision to leave the country to his nostalgic return. Another example of Walcott's feeling of ambivalence and uncertainty not only in his social life but in his literary life as well is his use of language. He is torn between adopting the standard traditional English or the Creole Caribbean and when he employs Caribbean style, he somehow feels as it is inadequate. In the following lines, Walcott remembers his apprenticeship period which is characterized by imitation. He says:

\section{I rendered}

The visible world that I saw

exactly, yet it hindered me, for

in every surface I sought

the paradoxical flash of an instant

in which every facet was caught

in a crystal of ambiguities,

I hoped that both disciplines might

by painful accretion cohere

and finally ignite,

but I lived in a different gift

its element metaphor(Collected Poems 200)

This part represents Walcott's desire as a poet to find coherence in "both disciplines", the English and the Caribbean, and that 
his desire to both capture every "facet" and "ambiguity" of his subject lead his attention away from the subject itself. Walcott also describes his style as "a different gift". Therefore, Walcott's style of writing is unique in the sense that it gathers between two different poles; the traditional and the Caribbean. In an interview with Sharon Ciccarelli, Walcott refers to his ability to write in both English and Creole language. He says:

I can't create in pure Creole, French, or English, for all sorts of reasons. You might be in a situation where accents differ within a small area, among people who all speak French Creole. The same applies to English Creole in the Caribbean....[B]ut since one considers the Caribbean- Englishspeaking Caribbean-as a whole, as sharing one language with various contributory sources, one must try to find, using syntaxes from different dialects if necessary, one form that would be comprehensible not only to the people in the region that speak in that tone of voice, but to people everywhere. (Walcott, Conversations 34)

As Another Life argues that Walcott succeeds to overcome the early period of ambivalence and dislocation of the Caribbean colonial period, it bridges the early feelings of fragmentation and strengthens the feeling of questing a new stage of literary development. In his article, "Some Subtleties of the Isle", John Figueroa comments on the themes in Another Life and says:

In Another Life.... one feels that the idea of the quest for home is being deepened. ... The meaning of place and history is not solved simplistically but enriched and accepted in all its complications; nothing is no longer only the 
experience of the negative, the depriving, the bitter. It is at the very least, the emptying that is the necessary condition of creativity.(151)

For Walcott, St.Lucia is not just the physical home where he was born, but it is the source of inspiration and creativity. In Chapter 22 of the work, Walcott reacts to the quest for the Caribbean home and shows his own feeling of pride of the Caribbean identity. Therefore, he employs the forms of repetition to stress his aim to celebrate the Caribbean pride. The repetition of the pronoun "I" assures the autobiographical aspects of Walcott's Caribbean experience:

I leapt for the pride of that race

at Sauteurs! An urge more than mine,

So, see them as heroes or as the Gadarene swine,

Let it be written, I shared, I shared,

I was struck like rock, and I opened

To His gift!

I laughed at my death-gasp in the rattle

of the sea-shoal. (Collected Poems 282)

From the very beginning of Another Life, Walcott tries hard to quest for the Caribbean identity and to make his Caribbean people internalize the feeling of pride and self- assertion. He was always searching "for the pride of that race" and "see them as heroes". Walcott uses repetition to stress his role in the struggle for the identity-making in a postcolonial context. The use of the repetition of the pronoun "I" in "I shared"and "I was struck like rock" documents the challenges and the tensions that Walcott went through in refiguring the Caribbean racial and cultural identity.

The last lines of Another Life demonstrate Walcott's contribution in the development of the Caribbean literature and 
language. Being an autobiography, the story-line of the poem follows the story-line of Walcott's life. The poem begins with "twilight" and the poet's feeling of ambivalence and it ends with "light". "The poem ends with a reaffirmation of the promise of part two, that the light of the world, once lit, never goes out entirely". (Breslin 188)

Gregorias, listen, lit,

We were the light of the world!

We were blest with a virginal, unpainted world

With Adam's task of giving things their names,

With the smooth white walls of clouds and villages.

(Collected Poems 294)

"In Another Life the pattern of pronouns shifts between first, second and third person is established from the outset" (Baugh, Derek Walcott 90). The change in the first person pronoun from "I" to "we" shows Walcott's concern about the communal life of the Caribbean and that the poem is not intended to depict only his ideas, but he changes his personal experience into a communal one. In the above lines, Walcott is addressing his friend Gregorias, who shared him the dream of creating Caribbean identity. "Another Life ends with restatement of the unfulfilled dream that Walcott and Gregorias had shared in their youth and which exalts the power of imagination through the image of 'light;"(Fumgalli 78).

\section{Conclusion}

Although Another Life represents a turning point in the history of Walcott's literary development, the style and the technique of writing is a little different from his early works. However, the adoption of some poetic techniques, using the vernaculars of the West Indian people and the portrayal of the persona enables Walcott to achieve his goal to quest the Caribbean cultural identity. Walcott developed 
the language of his poetry out of his own experience and the language he adopts emerges out of his multicultural heritage. This language provides the reader with cultural backgrounds and manipulates different social themes into continuing dialogue. The language employed by Walcott has transformative properties that can alter the cultural and social system. The researcher found that the strength of Walcott's Another Life is manifested not only in his great attention to the technical patterns but also in conducting the cultural experience of his West Indian heritage. As he himself experienced the conditions of colonialism and confronted its antagonism, Walcott's Another Life represents the dilemma and the ambivalence of the Caribbean people in a postcolonial society.

\section{Works Cited}

Alabi, Adetayo. "Recover, not Discover: Africa in Walcott's Dream on Monkey Mountain and Philip's Looking for Livingstone", The African Diaspora. Isidore Okpewho and et al eds. Bloomington and Indianapolis: Indiana University Press. 1999. 33243. Print.

Antoine-Dunne, Jean. Derek Walcott's Love Affair with

Film.Leeds: Peepal Tree Press Ltd, 2017.

Print.

Balakian, Peter. "The Poetry of Derek Walcott". Poetry, Vol.148. No.3 (June, 1986). pp.169-177. Web.

Baugh, Edward. Derek Walcott / Edward Baugh. . Cambridge, UK ; New York: Cambridge UP, 2006. Print.

Bhabha, Homi K. The Location of Culture. London ; New York: Routledge, 1994. Print.

Bobb, June D. Beating A Restless Drum: The Poetics of Kamau Brathwait and Derek 
Walcott. Trenton, Africa World Press. 1998. Print.

Breslin, Paul. Nobody's Nation: Reading Derek Walcott. Chicago and London. The University of Chicago Press. 2001.

Casteel, S. P. "Autobiography as Rewriting: Derek Walcott's Another Life and Omeros". The Journal of CommonwealthLiterature, 34(2) (1999), pp. 9-32. Web.

Ciccarelli, Sharon. "Reflections Before and After Carnival: An Interview with Derek Walcott". Conversations with Derek Walcott. William Baer, ed. Jackson: University Press of Mississippi, 1996. p.189. Print.

Dance, Daryl Cumber, ed. Fifty Caribbean Writers: A Bio- Bibliographical Critical Sourcebook. New York: Greenwood Press, 1986. Print.

Delmaire, Dominique . "Derek Walcott's Another Life: From Death to Celebration." E-rea : Revue D'etudes Anglophones 5.5.1 (2007): E-rea : Revue D'etudes Anglophones, 01 June 2007, Vol.5. Web.

Douillet, Catherine M. "The Quest for Caribbean Identities: Postcolonial Conflicts and CrossCultural Fertilization in Derek Walcott's Poetry." AmeriQuests 7.1 (2010): AmeriQuests, 02/02/2010, Vol.7(1). Web.

Dwyer, Richard. "One Walcott, and He Would Be Master". Caribbean Review 11.4 (1982): 14, 36- 37. Reprinted in Critical Perspectives on Derek Walcott, ed. Robert D.Hamner. Washington, DC: Three Continents Press, 1975:324-329. Print.

Fanon, Frantz, Sartre, Jean-Paul, and Farrington, Constance. The Wretched of the Earth. Pref. 
by Jean-Paul Sartre. Translated from the French by Constance Farrington. New York:

Grove, 1968. Print.

Fumagalli, Maria Cristina. The Flight of the Vernacular: Seamus Heaney, Derek Walcott and the Impress of Dante. New York: Rodopi B.V., 1994.Print.

Figueroa, John. "Some Subtleties of the Isle: A Commentary on Certain Aspects of Derek Walcott's Sonnet Sequence, Tales of the Islands." World Literature Written in English.

V 15, N.1 (197604) 190-228. Web.

Hambuch, Doris. "Geo-and Ecocritical considerations of Derek Walcott's Multitasking, Omnipresent Sea." International Journal of Applied Linguistics\& English Literature. Vol.4. No. 6; 2015. Web.

Hamner, Robert D., Derek Walcott. New York: Twayne Publishers, 1993.

- - - Epic of the Dispossessed: Derek Walcott's Omeros. Columbia and London: University of Missouri Press, 1997. Print.

Handley, George B. New World Poetics. Athens:

University of Georgia Press, 2007. Print.

Hardwick, Lorna, and Christopher Stray. "Introduction." A

Companion to Classical Receptions. Ed. Lorna Hardwick and Christopher Stray. Malden: Blackwell, 2008. pp. 1-10. Print.

Harris, Judith. "Giotto's Invisible Sheep: Lacanian Mirroring and Modeling in Walcott's 'Another Life.'(The Poetics of Derek Walcott: Intertextual Perspectives)." The South Atlantic Quarterly 96.2 (1997): 293. Web.

Hirsch, Edward, and Derek Walcott. "An Interview with Derek Walcott." Contemporary Literature, vol. 20, no. 3, 1979, pp. 279-292. Web. 
Hodges, Hugh. Soon Come: Jamaican Spirituality Jamaican Poetics. Charlottesville: University of Virginia Press, 2008. Print.

Ismond, Patricia. Abandoning Dead Metaphors: The Caribbean Phase of Derek Walcott's Poetry. Kingston: University of West Indies

Press, 200. Print.

- - -"The St Lucian Background in Garth St Omer and

Derek Walcott." Caribbean Quarterly 28, no. 1/2 (1982): 32-43. Web.

Izevbaye, D.S. "The Exile and the Prodigal: Derek Walcott as West Indian Poet." Caribbean Quarterly 26, no. 1/2 (1980): 70-82. Web.

King, Bruce. Derek Walcott: A Caribbean Life. New York:

Oxford University Press, 2000. Print.

Lai, Walton Look. "C.L.R.James and Trinidadian

Nationalism." C.L.R.James's Caribbean. Paget

Henry and Paul Buhle, eds. Durham: Duke University Press, 1992. Print.

Loreto, Paola. The Crowning of a poet's Quest: Derek

Walcott's Tiepolo's Hound. Amsterdam: New

York, 2009. Print.

McWatt, Mark A. "Derek Walcott: An Island Poet and His Sea." Third World Quarterly, vol. 10, no. 4, 1988, pp. 1607-1615. Web.

Nichols, Ashton. The Revolutionary "I" : Wordsworth and the Politics of Self-presentation / Ashton Nichols. New York: St. Martin's, 1998. Print.

Said, Edward. The World, the Text and the Critic. Massachusetts: Harvard UP,1983. Print.

- - - Culture and Imperialism / Edward W. Said. 1st Vintage Books ed. New York: Vintage, 1994. Print. 
Salkey, Andrew. "Inconsolable Songs of Our America: The Poetry of Derek Walcott." World Literature Today, vol. 56, no. 1, 1982, pp. 51-53. Web.

Terada, Rei. Derek Walcott's Poetry: American Mimicry.

Boston: Northeastern University Press. 1992.

Print.

Thieme, John. Derek Walcott: Contemporary World Writers.

Manchester and New York: Manchester University

Press. 1999.Print.

Derek Walcott. Collected Poems: 1948-1984. New York:

Farrar, Straus, \& Giroux, 1986. Print.

- - . "The Muse of History: An Essay." Is Massa Dead, Black Moods in The Caribbean. Ed. Orde Coombs.

New York: Anchor Press/ Doubleday, 1974, 1-27.

- - - Conversation with William Baer. Fourteen on Form:

Conversations with Poets. Ed. William Baer. The United

States of America: The University Press of

Mississippi. 1984. Print.

- - - and Edward Hirsch. "Poetry: Derek Walcott." The

Wilson Quarterly (1976), vol. 21, no. 4, 1997, pp. 109-114. Web.

- - . What the Twilight Says: Essays. New York:

Straus and Giroux, 1998. Print.

Zargarzadeh, Haleh. "Rhiz(h)Oming Achille: Walcott,

Glissant, and the Politics of Relation and

Creolization." Journal of Postcolonial Writing, vol. 53, no.6, 2017, pp. 715-728. Web. 